International Journal of Life Sciences
Available online at www.sciencescholar.us
Vol. 4 No. 1, April 2020, pages: 87-98
e-ISSN: 2550-6986, p-ISSN: 2550-6994
https://doi.org/10.29332/ijls.v4n1.407

\title{
Antioxidant Capacity Profile of Dewandaru Leaf (Extract Eugenia uniflora L.): Part of Usadha Bali
}

\author{
Puguh Santoso a, Ni Luh Kade Arman Anita Dewi b , Agus Adrianta c \\ Manuscript submitted: 27 January 2019 Manuscript revised: 18 February 2019, Accepted for publication: 09 March 2020
}

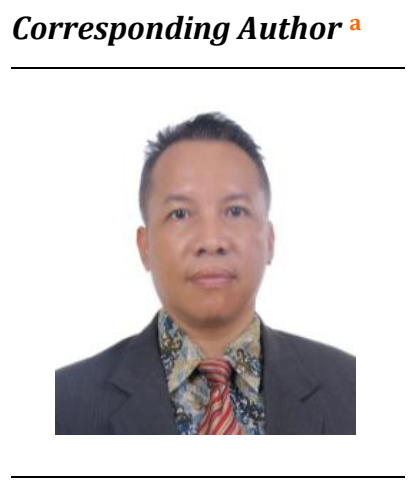

Keywords

antioxidant activities;

Dewandaru leaves

(Eugenia uniflora L);

IC50;

$D P P H ;$

Usadha Bali;

\begin{abstract}
Bali has around 50,000 usadha palm oil which is a source of untreated herbal medicine. One of the plants that have the potential as an antioxidant and is traditionally used by the community is Dewandaru (Eugenia uniflora L.) plant. Dewandaru containing tannins, flavonoids, and anthocyanins. Dewandaru plants have antibacterial activity, antioxidants, and antidotes to free radicals. Making extract with six different solvents, among them methanol, ethyl acetate, n-butanol, chloroform, and n-hexane. The measurements were taken of the reduction of free radical activity by observing the absorbance at the maximum wavelength with a UV-Vis spectrophotometer alternately on the six samples. Secondary metabolites contained in Dewandaru leaves, namely flavonoids, tannins, and quinones. The value obtained is IC50 methanol extract 5,857 ppm; n-butanol extract 8,893 ppm; ethyl acetate extract 15,203 ppm; n-hexane extract $162.7315 \mathrm{ppm}$; and chloroform extract 75,873 ppm. Methanol extract, n-butanol, and ethyl acetate have very strong antioxidant activity because $<50$ ppm; n-hexane extract has weak antioxidant activity (ranging from 150-200 ppm), and chloroform extract has strong antioxidant activity (ranging from 50$100 \mathrm{ppm}$ ). Major conclusions: Dewandaru leaves has the potential as a natural antioxidant in the treatment section of Usadha Bali.
\end{abstract}

International Journal of Life Sciences (C) 2020. This is an open access article under the CC BY-NC-ND license (https://creativecommons.org/licenses/by-nc-nd/4.0/).

\section{Contents}

Abstract

1 Introduction...

2 Materials and Methods 89

3 Results and Discussions 91

3.1 The result of simplistic and maceration production.

\footnotetext{
a Universitas Mahasaraswati, Denpasar, Indonesia

b Universitas Mahasaraswati, Denpasar, Indonesia

c Universitas Mahasaraswati, Denpasar, Indonesia
} 




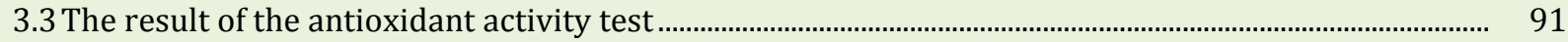



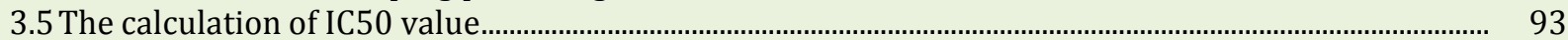

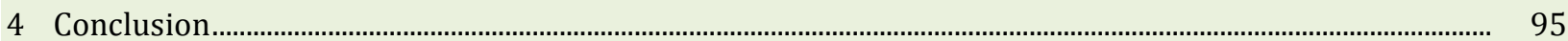

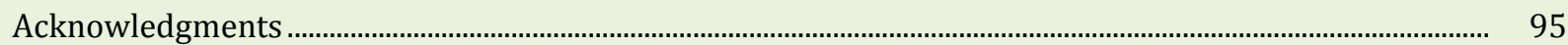

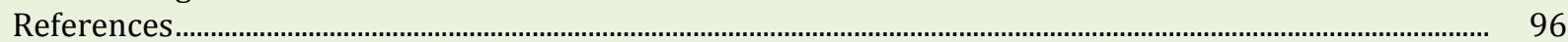

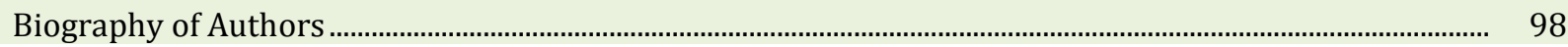

\section{Introduction}

Various sources of free radicals can be found in our daily life, such as vehicle and factory smoke, radiation, food, and the result of the body's oxidation process. Free radicals are atoms or groups which have one or more unpaired electrons. The antioxidant is a compound which can obstruct the oxidation reaction by binding free radicals and molecule which are very reactive, therefore cell damage can be obstructed. This compound has lightweight of molecule but it can inactivate the development of oxidation reaction by preventing radical forming.

Usadha Balinese traditional healing science has not been scientifically developed either for the purpose of healing or for local drink. Moreover, it has not been developed globally yet. Bali has about 50.000 lontar usadha, the literature of herbal healing, which is not well developed. If it was developed properly, it could improve people's health and economic issues because its cost is relatively low and it does not have chemical impacts (Sutomo \& Iryadi, 2019).

A health problem can be reviewed by health economic science. One of the medical plants which are used as medicine by Balinese traditional healer is Dewandaru. The use of traditional medical plants has not been developed scientifically. Therefore, nobody knows how its contents can heal people (Akrishnan, 2018). Its use is just based on people's beliefs, experience, and testimonies from the healed patients (Rasna et al., 2017).

Nowadays many people seek alternative medication by using traditional medicine such as herbal medicine because its process is more natural, original, and relatively safe without any side effects like the synthesized medicines (Ekor, 2014). Traditional medicine is a medicine made of plants, animals, minerals of the mix of them (Yuan et al., 2016). A plant can have a healing effect because it has phytochemical contents or secondary metabolites (Mulyani et al., 2016).

One of the plants which potentially functions as antioxidant and has been traditionally used by the society is Dewandaru (Eugenia uniflora L.). It contains tannin, vitamin C, an essential compound like cineol, citronella, sesquiterpene, flavonoid, and anthocyanin. Dewandaru has an antibacterial, antioxidant, free radical antidote, hydrolysis and enzyme oxidation resistor, and anti-inflammation (Santoso, 2018).

The use of synthetic antioxidants nowadays gets serious attention because it is harmful and carcinogenic (Mbah et al., 2019). Therefore, currently, a research is conducted regarding antioxidant development which made of natural resources that can be easily found, cheap and safe to be consumed by people (Atta et al., 2017). However, scientific research toward phytochemical content and antioxidant activity of Dewandaru leaves extract has never been done. Although there are a lot of Dewandaru leaves available in Bali which is one of medical plants as mentioned in Usadha Bali.

From the explanation above, the researcher is interested in researching Dewandaru leaf extract which grows in Bali province. First of all, the researcher will do a phytochemical screening of Dewandaru leaves extract to find out secondary metabolites contained in Dewandaru leaves extract. Then conducting antioxidant activity tests as scientific proof to discover the property of that plant (Oliveira et al., 2006; Consolini et al., 1999; Victoria et al., 2012; Mielke \& Schaffer, 2010). 


\section{Materials and Methods}

\section{Research plan}

This research is a laboratory descriptive research using the DPPH method to examine the antioxidant activity of Dewandaru leaves extract by using solvents such as methanol, n-butanol, ethyl acetate, n-hexane, and chloroform.

\section{Materials}

A sample that used in this research is Dewandaru leaves which taken from all over Bali which has been determined at LIPI. Chemical materials which used in this research such as ethyl acetate (Merck), n-butanol (Merck), methanol (Merck), standard DPPH (2,2-difenil-1-pikrilhidrazil) (Merck), ethanol 96\% (Merck), HCl 2N (Merck), dragendorff reagent (Merck), mayer reagent (Merck), Pb acetate 10\% (Merck), aquadest (Merck), $\mathrm{FeCl} 5 \%$ or $\mathrm{FeCl} 10 \%$ (Merck), chloroform (Merck), anhydrous acetic acid (Merck), dense sulfuric acid (Merck), and $\mathrm{NaOH} 1 \mathrm{~N}$ (Merck).

\section{Method \\ Dewandaru leaves extraction}

Dewandaru leaves are picked from Bali areas (Abiansemal, Jl. Cargo Tanan No. 20 Denpasar, and Renon), they are then dried in the oven with temperature $40^{\circ} \mathrm{C}$. After that, they are blended into a powder. 200 -gram simplistic of Dewandaru leaves powder is weighed. Then it is macerated by using solvent (n-buthanol, methanol, ethyl acetate, chloroform, and n-hexane) as much as $600 \mathrm{ml}$ in a glass jar and stirred constantly for one hour. And then it is covered by aluminum foil and plastic wrap and hushed for three days (it must be stirred every day for 30 minutes). After three days, the extract is filtered manually and dried in the oven with temperature $40^{\circ} \mathrm{C}$.

\section{Phytochemical Screening}

Phytochemical screening of Dewandaru leaves extract includes an examination of compound groups such as Alkaloid, Flavonoid, Saponin, Tannin, Steroid/Triterpenoid, and Quinone.

a) Alkaloid

$2 \mathrm{ml}$ test solution is veporized on the porcelain cup until obtaining the residue. The residue is then dissolved with $5 \mathrm{ml} \mathrm{HCl} 2 \mathrm{~N}$. After it is cold, then it is filtered. The obtained solution then divided into 3 test tubes. The first test-tube functions as blank. The second test tube is added with 3 drops of dragendorff reagent and the third test tube is added with 3 drops of Mayer reagent (through the tube wall). The formation of orange sediment in the second tube and yellow sediment in the third tube show the existence of Alkaloid (Susanti et al., 2014).

b) Flavonoid $1 \mathrm{ml}$ test solution is added with $1 \mathrm{ml} \mathrm{Pb}$ acetate $10 \%$ (lead acetate), it positively contains flavonoid if there was yellow sediment (Natalia, 2016).

c) Saponin

$50 \mathrm{ml}$ test solution is added with $5 \mathrm{ml}$ aqua dest, then it is shaken for 10 seconds. If the foam is formed (1$10 \mathrm{~cm}$ height) in less than 10 minutes and it does not vanish when 1 drop of $\mathrm{HCl} 2 \mathrm{~N}$ is added, it shows the existence of Saponin (Susanti et al., 2014).

d) Tannin

$2 \mathrm{ml}$ test solution is added with several drops of $\mathrm{FeCl}_{3} 5 \%$ or $\mathrm{FeCl}_{3} 10 \%$. The formation of dark green or blue solution shows the existence of tannin (Natalia, 2016).

e) Steroid/Triterpenoid

$2 \mathrm{ml}$ test solution is veporized in a vaporizer cup. The residue is dissolved with $3 \mathrm{ml}$ chloroform, then moved into the test tube. After that, it is added by $3 \mathrm{ml}$ anhydrate acetate acid and $2 \mathrm{ml}$ dense sulfuric acid through the tube wall. The formation of a brown or violet ring on the solution border shows the existence of a triterpenoid, while if greenness blue rings appeared it shows the existence of steroids (Susanti et al., 2014).

Santoso, P., Dewi, N. L. K. A. A., \& Adrianta, A. (2020). Antioxidant capacity profile of dewandaru leaf (extract eugenia uniflora l.): part of usadha Bali. International Journal of Life Sciences, 4(1), 87-98. 
f) Quinone

$5 \mathrm{ml}$ test solution is added with several drops of $\mathrm{NaOH} 1 \mathrm{~N}$, the formation of the red solution shows the existence of the quinone compound (Natalia, 2016).

\section{Antioxidant activity test}

Antioxidant activity test toward Dewandaru leaves extract is conducted by using ethyl acetate and n-buthanol solvent as seen in the following steps:

a) The Making of Master Raw Solution

Dewandaru leaves extract with ethyl acetate solvent is macerated with $\mathrm{n}$-butanol to create a master raw solution in concentration $100 \mathrm{ppm}$ as much as $50 \mathrm{ml} .5 \mathrm{mg}$ dry extract is dissolved by methanol inside the volumetric flask $50 \mathrm{ml}$ until meeting the border mark. Then it is shaken until homogeneous.

b) The Making of Standard Working Solution

Dewandaru leaves extract with ethyl acetate and n-buthanol $100 \mathrm{ppm}$ diluted into concentration $20 \mathrm{ppm} .4$ $\mathrm{ml}$ of master raw solution $100 \mathrm{ppm}$ is dissolved by methanol inside volumetric flask $10 \mathrm{ml}$ until meeting the border mark. Then it is shaken until homogeneous.

c) The Making of Test Sample Solution

From standard working solution $20 \mathrm{ppm}$ ethyl acetate and n-buthanol extract of Dewandaru leaves are made into concentration 2; 4; 6; 8; 10 and 12 ppm by taking $1 ; 2 ; 3 ; 4 ; 5$ and 6 ml. Each of them is put inside a volumetric flask $10 \mathrm{ml}$. Then it is added by methanol until meeting the border mark. After that, it is shaken until homogeneous.

Solution $20 \mathrm{ppm}$ is taken 1, 2, 3, 4, 5, and $6 \mathrm{ml}$. Then each of them is put inside volumetric flask $20 \mathrm{ml}$ and added by methanol until meeting the border mark. That solution is shaken until it creates a test solution with concentrations $1,2,3,4,5$, and 6 ppm.

$25 \mathrm{ml}$ of $100 \mathrm{ppm}$ solution is dissolved with methanol inside volumetric flask $50 \mathrm{ml}$ until meeting the border mark. Then it is shaken until homogenous and becomes 50 ppm solution. 50 ppm solution of $n-$ hexane and chloroform extract is then taken 1, 2, 3, 4, 5, 6, and $7 \mathrm{ml}$. After that, each of them is put into a volumetric flask $10 \mathrm{ml}$ and added by methanol until meeting the border mark. That solution is shaken, so it becomes a test solution with concentration $5,10,15,20,25,30$, and $35 \mathrm{ppm}$.

d) The Making of Master Raw Solution DPPH with Concentration 100 ppm

Scaling $5 \mathrm{mg}$ of DPPH powder then put it into volumetric flask $50 \mathrm{ml}$. It is added by methanol ad $50 \mathrm{ml}$ and shaken until homogenous.

e) The Making of Standard Working Solution DPPH with Concentration $40 \mathrm{ppm}$

$20 \mathrm{ml}$ standard solution DPPH concentration $100 \mathrm{ppm}$ is taken and put into volumetric flask $50 \mathrm{ml}$ and added by methanol until meeting the border mark. It is shaken until homogenous.

f) The Determination of Maximum Wavelength of DPPH 40 ppm Solution

$4 \mathrm{ml}$ standard solution DPPH $40 \mathrm{ppm}$ is taken and put into the cuvette, then its absorption spectrum is observed in wavelength $400-800 \mathrm{~nm}$ with spectrophotometer UV-Vis. $4 \mathrm{ml}$ methanol is used for the blank solution. The maximum wavelength can be determined from the absorption curve.

g) The Measurement of DPPH Absorbance

$4 \mathrm{ml}$ standard solution DPPH $40 \mathrm{ppm}$ is taken $4 \mathrm{ml}$ and put into the cuvette, then its absorption spectrum is observed in wavelength 400-800 $\mathrm{nm}$ with spectrophotometer UV-Vis. $4 \mathrm{~mL}$ methanol is used for the blank solution. The maximum wavelength can be determined from the absorption curve.

h) The Measurement of DPPH Free Radicals Damping Activity with Spectrophotometer UV-Vis

The measurement of free radical activity is done by taking $2 \mathrm{ml}$ liquid DPPH $40 \mathrm{ppm}$. It is put into the test tube and added by $2 \mathrm{ml}$ test solution from each concentration, shaken until homogenous and then hushed for 30 minutes. After that, observing the absorption in the maximum wavelength by using spectrophotometry UV-Vis in turn toward six concentrations for each test sample. The absorption of each extract is noted.

i) Determination of IC50 Value and the Making of Calibration Curve

From the absorbance result of each tested concentration, the damping percentage value is obtained by using the following formula: 


$$
\% \text { damping }=\frac{\text { absorbance DPPH }- \text { absorbance of test sample }}{\text { absorbance DPPH }} \times 100 \%
$$

From the damping percentage on each concentration, then the regression curve is made, so the equation is $\mathrm{y}=$ $\mathrm{bx}+\mathrm{a}$ and the result will be $I C_{50}$ by the calculation in a linear regression where the extract concentration (ppm) as a basis (the x-axis) and subtuance percentage as ordinate (the y-axis) (Astawa et al., 2017; Arora et al., 1998; Jayaprakasha et al., 2003; Matalon et al., 1990; Al-Mamary et al., 2002). The value of $I C_{50}$ is found from the calculation of a damping percentage of $50 \%$.

From the subtuance percentage of each concentration, then regression curve is made, so the equation is found $\mathrm{y}=\mathrm{bx}+\mathrm{a}$ and the result will be $I C_{50}$ by the calculation in a linear regression where the extract concentration (ppm) as a basis (the x-axis) and subtuance percentage as ordinate (the y-axis). The value of $I C_{50}$ is found from $50 \%$ subtuance.

\section{Results and Discussions}

\subsection{The result of simplistic and maceration production}

Dried Dewandaru leaves are refined by using a blender. Simplisia powder of Dewandaru leaves is then macerated by using ethyl acetate and n-butanol solvent. After the maserat is obtained, then it is concentrated which produces dried Dewandaru leaves extract with ethyl acetate solvent 2.5742 gram and dried Dewandaru leaves extract with n-butanol solvent 1.3558 gram.

\subsection{Phytochemicals screening result}

Phytochemicals screening is done to find out the secondary metabolite content of Dewandaru leaves extract. Screening results of a secondary metabolite which positively contained in Dewandaru leaves in methanol, $\mathrm{n}$ butanol, dan ethyl acetate extract are flavonoids, tannin, and quinone. Whereas its $n$-hexane and chloroform extract only positively contain flavonoid (Chhabra et al., 1984; Tona et al., 1998; Naz \& Bano, 2013).

Based on phytochemicals screening results of the extract mentioned in table 1, it shows that methanol, $\mathrm{n}$ butanol, and ethyl acetate of Dewandaru leaves extract (Eugenia uniflora L.) positively contain flavonoids, tannin, and quinone compound. While in alkaloid testing, saponin, steroid, and terpenoid show a negative result. The screening result of n-hexane and chloroform only positively contain flavonoid. It is due to no color change or sediment when it is added by reagents in the testing process. Flavonoids, phenolic, and tannin are phenol compounds that have a bunch $-\mathrm{OH}$ which tied in aromatic ring carbon. Flavonoid ability is very potential for antioxidant because of its molecule structure and hydroxyl bunch position (Agati et al., 2012).

The result of the research shows that Dewandaru leaves positively contain flavonoids since there is yellow sediment on the sample which is reacted with $\mathrm{Pb}$ acetate condensation $10 \%$. It is because the flavonoids have a benzene ring which has a hydroxyl bunch (Natalia, 2016).

Tannin testing is done by adding $\mathrm{FeCl}_{3}$ which reacts with one of the hydroxyl rings that exist in tannin (Natalia, 2016). From this research, Dewandaru leaves positively contain tannin which can be seen from the formation of dark green solutions. Quinone testing is done by adding several drops of $\mathrm{NaOH} 1 \mathrm{~N}$ into the test solution. The result shows it positively contains the quinone compound by the formation of a red solution. This research shows that Dewandaru leaves extract to contain a quinone compound because of the formation of a brownish-red solution.

\subsection{The result of the antioxidant activity test}

Antioxidant activity test in Dewandaru leaves extract with methanol solvent is done in concentration $1 \mathrm{ppm}, 2$ ppm, $3 \mathrm{ppm}, 4 \mathrm{ppm}, 5 \mathrm{ppm}$, dan $6 \mathrm{ppm}$. Ethyl acetate extract and n-butanol are done in concentration $2 \mathrm{ppm}$, $4 \mathrm{ppm}, 6 \mathrm{ppm}, 8 \mathrm{ppm}, 10 \mathrm{ppm}$, dan $12 \mathrm{ppm}$. N-hexane dan chloroform extract is done in concentration 5, 10,

Santoso, P., Dewi, N. L. K. A. A., \& Adrianta, A. (2020). Antioxidant capacity profile of dewandaru leaf (extract eugenia uniflora l.): part of usadha Bali. International Journal of Life Sciences, 4(1), 87-98.

https://doi.org/10.29332/ijls.v4n1.407 
$15,20,25,30$, and 35 ppm which added by DPPH standard solution $40 \mathrm{ppm}$. The absorption is then measured by spectrophotometer UV-Vis. The measurement result of test sample absorption is presented in the following table:

Table 1

Screening Result of Dewandaru Leaves Extract

\begin{tabular}{lllllll}
\hline \multirow{2}{*}{ Test } & Reactor & Methanol & $\begin{array}{l}\text { n- } \\
\text { butanol }\end{array}$ & $\begin{array}{l}\text { ethyl } \\
\text { acetate }\end{array}$ & n-hexane & Chloroform \\
\hline Alkaloids & Dragendorff & $(-)$ & $(-)$ & $(-)$ & $(-)$ & $(-)$ \\
& Mayer & $(-)$ & $(-)$ & $(-)$ & $(-)$ & $(-)$ \\
Flavonoids & Pb acetate 10\% & $(+)$ & $(+)$ & $(+)$ & $(+)$ & $(+)$ \\
Saponin & Aquadest $+\mathrm{HCl} 2 \mathrm{~N}$ & $(-)$ & $(-)$ & $(-)$ & $(-)$ & $(-)$ \\
Tannin & FeCl $5 \%$ or $\mathrm{FeCl}_{3}$ 10\% & $(+)$ & $(+)$ & $(+)$ & $(-)$ & $(-)$ \\
Steroid/Trit & Anhydrant Acetate Acid + & $(-)$ & $(-)$ & $(-)$ & $(-)$ & $(-)$ \\
erpenoid & Concentrated Sulfuric Acid & & & & & $(-)$ \\
Quinone & Solution & $(+)$ & $(+)$ & $(+)$ & $(-)$ & $(-)$ \\
& NaOH 1 N & & & & & \\
\hline
\end{tabular}

Table 2

The Absorbance of Dewandaru Leaves Extract Concentration with Some Solvent

\begin{tabular}{|c|c|c|c|c|c|c|}
\hline \multirow[b]{2}{*}{ No } & \multirow[b]{2}{*}{ Solution } & \multicolumn{5}{|c|}{ Absorbance } \\
\hline & & $\begin{array}{l}\text { Methanol } \\
\text { Solven }\end{array}$ & $\begin{array}{l}\text { n-Butanol } \\
\text { Solven }\end{array}$ & $\begin{array}{l}\text { Ethyl } \\
\text { Acetate } \\
\text { Solvent }\end{array}$ & $\begin{array}{l}\text { n-Hexane } \\
\text { Solvent }\end{array}$ & $\begin{array}{l}\text { Chloroform } \\
\text { Solvent }\end{array}$ \\
\hline 1 & Control & 0.387 & 0.426 & 0.375 & 0.378 & 0.274 \\
\hline 2 & $1 \mathrm{ppm}$ & 0.344 & - & - & - & - \\
\hline 3 & $2 \mathrm{ppm}$ & 0.322 & 0.391 & 0.357 & - & - \\
\hline 4 & 3 ppm & 0.289 & - & - & - & - \\
\hline 5 & $4 \mathrm{ppm}$ & 0.254 & 0.372 & - & - & - \\
\hline 6 & $5 \mathrm{ppm}$ & 0.220 & - & - & - & 0.268 \\
\hline 7 & $6 \mathrm{ppm}$ & - & 0.354 & 0.337 & - & - \\
\hline 8 & $8 \mathrm{ppm}$ & - & 0.331 & 0.326 & - & - \\
\hline 9 & 10 ppm & - & 0.311 & 0.313 & - & 0.259 \\
\hline 10 & 12 ppm & - & 0.274 & 0.298 & - & - \\
\hline 11 & 15 ppm & - & - & - & 0.38 & 0.26 \\
\hline 12 & 20 ppm & - & - & - & 0.37 & 0.23 \\
\hline 13 & 25 ppm & - & - & - & 0.36 & - \\
\hline 14 & 35 ppm & - & - & - & 0.34 & - \\
\hline
\end{tabular}

Based on the table above it can be discovered that the absorbance of each compound is decreased. The bigger the concentration of the test sample solution, the smaller the absorbance of DPPH $40 \mathrm{ppm}$. It means DPPH as the free radicals have been able to be reduced by the antioxidant which exists in test sample solution which marked by the decrease of the absorbance. 
3.4 The calculation of damping percentage

Based on the absorbance which obtained from the six concentration sample, then damping percentage is calculated by using the following formula:

$$
\text { \%damping }=\frac{\text { DPPH absorbance }- \text { test sample absorbance }}{\text { DPPH absorbance }} \times 100 \%
$$

Table 3

Damping percentage of Dewandaru leaves extract with some solvent

\begin{tabular}{|c|c|c|c|c|c|c|}
\hline \multirow[t]{2}{*}{ No } & \multirow[t]{2}{*}{ Solution } & \multicolumn{5}{|c|}{ Damping Percentage (\%) } \\
\hline & & $\begin{array}{l}\text { Methanol } \\
\text { Solven }\end{array}$ & $\begin{array}{l}\text { n-Butanol } \\
\text { Solven }\end{array}$ & $\begin{array}{l}\text { Ethyl Acetate } \\
\text { Solvent }\end{array}$ & $\begin{array}{l}\text { n-Hexane } \\
\text { Solvent }\end{array}$ & $\begin{array}{l}\text { Chloroform } \\
\text { Solvent }\end{array}$ \\
\hline 1 & $1 \mathrm{ppm}$ & 11.11 & - & - & - & - \\
\hline 2 & $2 \mathrm{ppm}$ & 16.79 & 8.22 & 4.8 & - & \\
\hline 3 & $3 \mathrm{ppm}$ & 25.32 & - & - & - & - \\
\hline 5 & $5 \mathrm{ppm}$ & 43.15 & - & - & - & 2.18 \\
\hline 6 & $6 \mathrm{ppm}$ & - & 16.90 & 10.13 & - & - \\
\hline 7 & $8 \mathrm{ppm}$ & - & 22.30 & 13.06 & - & - \\
\hline 8 & $10 \mathrm{ppm}$ & - & 26.99 & 16.53 & - & 5.47 \\
\hline 9 & $12 \mathrm{ppm}$ & - & 35.68 & 20.53 & - & - \\
\hline 10 & $15 \mathrm{ppm}$ & - & - & - & 0.26 & 6.56 \\
\hline 11 & $20 \mathrm{ppm}$ & - & - & - & 2.38 & 14.59 \\
\hline 12 & $25 \mathrm{ppm}$ & - & - & - & 5.29 & - \\
\hline 13 & 35 ppm & - & - & - & 11.37 & - \\
\hline
\end{tabular}

Based on the table above, it can be seen that the damping percentage of each concentration increases. The bigger the concentration of the test sample solution, the higher the damping percentage. It means that the more the antioxidant in the test sample solution, the more the free radicals damping. It is marked by the increase of free radicals damping percentage.

\subsection{The calculation of IC 50 value}

The calculation of $I C_{50}$ value is done by making a relationship curve between the concentration of the test sample and damping percentage so that the linear regression equation is $y=b x+a$, where $x$ is $p p m$ concentration and y is $I C_{50}$ percentage (Okoh et al., 2014). The result can be seen in Figures 3 and 4.

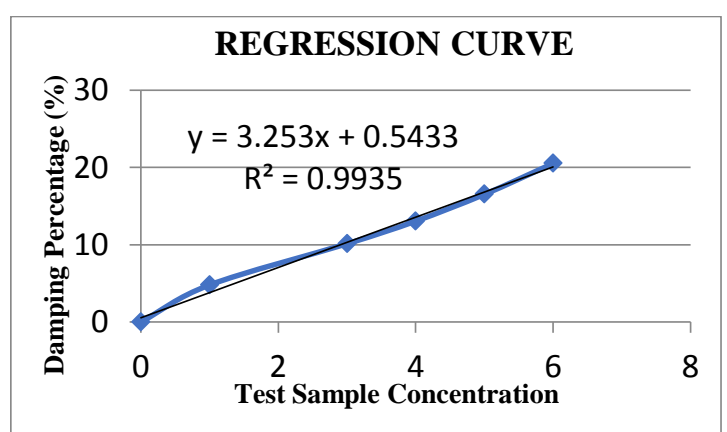

Figure 1. The curve of Ethyl Acetate Extract



Figure 2. The curve of n-Butanol Extract

Santoso, P., Dewi, N. L. K. A. A., \& Adrianta, A. (2020). Antioxidant capacity profile of dewandaru leaf (extract eugenia uniflora l.): part of usadha Bali. International Journal of Life Sciences, 4(1), 87-98. https://doi.org/10.29332/ijls.v4n1.407 




Figure 3. The curve of Methanol Extract

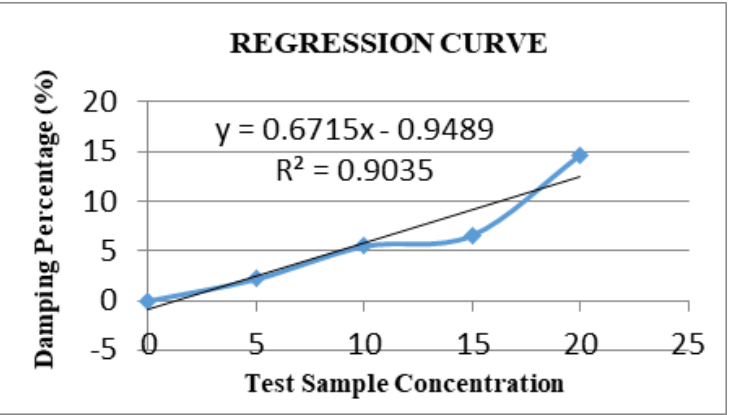

Figure 4. The curve of Chloroform Extract

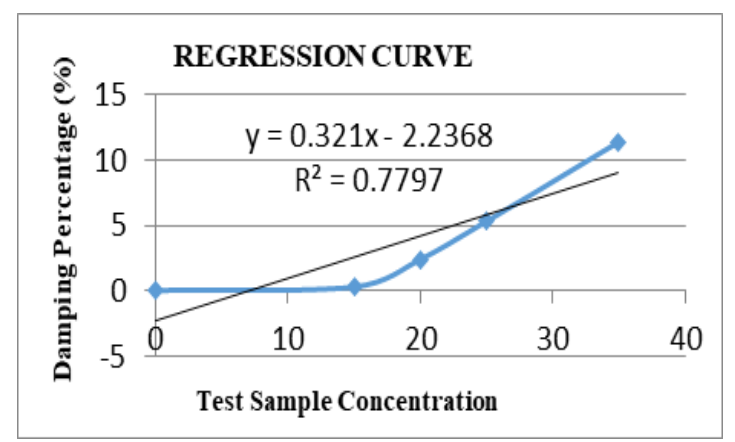

Figure 5. The curve of n-Hexane Extract

Based on Figure 1, relationship curve between the concentration of test solution and damping percentage, the regression equation is $\mathrm{y}=3,253 \mathrm{x}+0,5433, \mathrm{R}^{2}=0,9935$. From that equation, then the calculation of $I C_{50}$ value is done by replacing the value of $y=50$.

Based on Figure 2, relationship curve between the concentration of test solution and damping percentage, the regression equation is $y=5,508 x+1,0144, R^{2}=0,988$. Based on Figure 3, relationship curve between the concentration of test solution and damping percentage, the regression equation is $y=3.253 x+0.5433, R^{2}=$ 0.9935. Based on Figure 4, relationship curve between the concentration of test solution and damping percentage, the regression equation is $\mathrm{y}=0.6725 \mathrm{x}-0.9489, \mathrm{R}^{2}=0.9035$. Based on Figure 5 , relationship curve between the concentration of test solution and damping percentage, the regression equation is $\mathrm{y}=$ $0.321 \mathrm{x}-2.2368, \mathrm{R}^{2}=0.7797$.

This research shows that Dewandaru leaves extract has an antioxidant activity which marked by the existence of flavonoid secondary metabolite content which functions to muffle free radicals. The value of $I C_{50}$ Dewandaru leaves methanol extract $=5.857 \mathrm{ppm}$, the value of $I C_{50}$ Dewandaru leaves n-butanol extract $=8.893$ $\mathrm{ppm}$, the value of $I C_{50}$ Dewandaru leaves ethyl acetate extract $=15.203 \mathrm{ppm}$, the value of $I C_{50}$ Dewandaru leaves n-hexane extract $=162.7315 \mathrm{ppm}$, and the value of $I C_{50}$ Dewandaru leaves chloroform extract $=75.873$ ppm. Therefore, Dewandaru leaves extract is potentially used as part of Usadha Bali treatment as a natural antioxidant that can be used by society.

Table 4

Antioxidant properties based on $I C_{50}$ value

\begin{tabular}{ll}
\hline$I C_{50}$ Value & Antioxidant properties \\
\hline $50 \mathrm{ppm}<$ & Very Strong \\
$50 \mathrm{ppm}-100 \mathrm{ppm}$ & Strong \\
$100 \mathrm{ppm}-150 \mathrm{ppm}$ & Medium \\
$150 \mathrm{ppm}-200 \mathrm{ppm}$ & Weak \\
\hline
\end{tabular}


The result of the research shows that methanol extract, n-butanol and ethyl acetate of Dewandaru leaves are classified into a very strong category of the antioxidant compounds because of the value of $I C_{50}$ is less than 50 ppm. Meanwhile, chloroform extract is classified into a strong category of the antioxidant compound and the $\mathrm{n}$-hexane extract is classified into a medium category of the antioxidant compound.

\section{Conclusion}

Based on the research result, it can be concluded that:

a) Based on the result of the phytochemical screening test of Dewandaru leaves with methanol solvent, ethyl acetate, and n-butanol, it is found that Dewandaru leaves positively contain flavonoids, tannin and quinone compound. While n-hexane and chloroform extract positively contain flavonoids only.

b) Dewandaru leaves have antioxidant activity.

Based on antioxidant activity test of Dewandaru leaves, it shows that the use of n-butanol solvent produces $I C_{50}$ value $=8.893 \mathrm{ppm}$, ethyl acetate solvent produces $I C_{50}$ value $=15.203 \mathrm{ppm}$, Dewandaru leaves methanol extract produces $I C_{50}$ value $=5.857 \mathrm{ppm}$, Dewandaru leaves chloroform extract produces $I C_{50}$ value $=75.873$ ppm, $I C_{50}$ value of Dewandaru leaves' ethyl acetate extract is $15.203 \mathrm{ppm}$. Based on the table of Dewandaru leaves' antioxidant properties, methanol, n-butanol, and ethyl acetate extract are classified into a very strong category of the antioxidant compound because its $I C_{50}$ value is less than $50 \mathrm{ppm}$, while the chloroform extract classified into a strong category of the antioxidant compound and n-hexane extract classified into a medium category of the antioxidant compound.

\section{Acknowledgments}

This research was supported by the Faculty of Pharmacy Mahasaraswati University. Thank you, the authors say to the students who have helped with this research, including them Prema Wahini, Novia Hariantini, and Fitri Ekayanti.

Santoso, P., Dewi, N. L. K. A. A., \& Adrianta, A. (2020). Antioxidant capacity profile of dewandaru leaf (extract eugenia uniflora l.): part of usadha Bali. International Journal of Life Sciences, 4(1), 87-98. 


\section{References}

Agati, G., Azzarello, E., Pollastri, S., \& Tattini, M. (2012). Flavonoids as antioxidants in plants: location and functional significance. Plant science, 196, 67-76. https://doi.org/10.1016/j.plantsci.2012.07.014

Akrishnan, S.S. (2018). Traditional Herbal Medicines-A Review, IJRAR, 5,(4).

Al-Mamary, M., Al-Meeri, A., \& Al-Habori, M. (2002). Antioxidant activities and total phenolics of different types of honey. Nutrition research, 22(9), 1041-1047. https://doi.org/10.1016/S0271-5317(02)00406-2

Arora, A., Nair, M. G., \& Strasburg, G. M. (1998). Antioxidant activities of isoflavones and their biological metabolites in a liposomal system. Archives of biochemistry and biophysics, 356(2), 133-141. https://doi.org/10.1006/abbi.1998.0783

Astawa, P., Jawi, I. M., \& Sabir, A. (2017). Antioxidant activity of apis mellifera sp. propolis extract from Java (Indonesia). International research journal of engineering, IT \& scientific research, 3(5), 19-24.

Atta, E. M., Mohamed, N. H., \& Abdelgawad, A. A. (2017). Antioxidants: An overview on the natural and synthetic types. Eur. Chem. Bull, 6, 365-375.

Chhabra, S. C., Uiso, F. C., \& Mshiu, E. N. (1984). Phytochemical screening of Tanzanian medicinal plants. I. Journal of ethnopharmacology, 11(2), 157-179. https://doi.org/10.1016/0378-8741(84)90037-0

Consolini, A. E., Baldini, O. A., \& Amat, A. G. (1999). Pharmacological basis for the empirical use of Eugenia uniflora L.(Myrtaceae) as antihypertensive. Journal of ethnopharmacology, 66(1), 33-39. https://doi.org/10.1016/S0378-8741(98)00194-9

Ekor, M. (2014). The growing use of herbal medicines: issues relating to adverse reactions and challenges in monitoring safety. Frontiers in pharmacology, 4, 177. https://doi.org/10.3389/fphar.2013.00177

Jayaprakasha, G. K., Selvi, T., \& Sakariah, K. K. (2003). Antibacterial and antioxidant activities of grape (Vitis vinifera) seed extracts. Food research international,36(2), 117-122. https://doi.org/10.1016/S09639969(02)00116-3

Matalon, S., Holm, B. A., Baker, R. R., Whitfield, M. K., \& Freeman, B. A. (1990). Characterization of antioxidant activities of pulmonary surfactant mixtures. Biochimica et Biophysica Acta (BBA)-General Subjects, 1035(2), 121-127. https://doi.org/10.1016/0304-4165(90)90105-6

Mbah, C.J., Ifeoma O., Ndiamaka H.O. (2019), Antioxidants Properties of Natural and Synthetic Chemical Compounds : Theraupetic Effects on Biological System, ACTA Scientific Pharmaceutical Sciences, 3.

Mielke, M. S., \& Schaffer, B. (2010). Photosynthetic and growth responses of Eugenia uniflora L. seedlings to soil flooding and light intensity. Environmental and Experimental Botany,68(2), 113-121. https://doi.org/10.1016/j.envexpbot.2009.11.007

Mulyani, H., Widyastuti, S. H., \& Ekowati, V. I. (2016). Tumbuhan herbal sebagai jamu pengobatan tradisional terhadap penyakit dalam serat Primbon Jampi Jawi jilid I. Jurnal Penelitian Humaniora UNY, 21(2), 124817.

Natalia, A.H.S. (2016). Skrining Fitokimia dan Aktivitas Antioksidan Ekstrak Metanol Daun Rinu (Piper baccatum BI.), Skripsi, Fakultas Farmasi Universitas Sanata Dharma, Yogyakarta.

Naz, R., \& Bano, A. (2013). Phytochemical screening, antioxidants and antimicrobial potential of Lantana camara in different solvents. Asian Pacific Journal of Tropical Disease, 3(6), 480-486. https://doi.org/10.1016/S2222-1808(13)60104-8

Okoh, S. O., Asekun, O. T., Familoni, O. B., \& Afolayan, A. J. (2014). Antioxidant and free radical scavenging capacity of seed and shell essential oils extracted from Abrus precatorius (L). Antioxidants, 3(2), 278-287. https://doi.org/10.3390/antiox3020278

Oliveira, A. L., Lopes, R. B., Cabral, F. A., \& Eberlin, M. N. (2006). Volatile compounds from pitanga fruit (Eugenia uniflora L.). Food Chemistry, 99(1), 1-5. https://doi.org/10.1016/j.foodchem.2005.07.012

Rasna, I. W., \& Tantra, D. K. (2017, August). Medical Plants in Usadha: Loloh as Balinese Medicine and Traditional Herbal Product in Educational Perspective. In 2nd International Conference on Innovative Research Across Disciplines (ICIRAD 2017). Atlantis Press. https://dx.doi.org/10.2991/icirad-17.2017.36

Santoso, P., Sari, N. W. B., Yuda, P. E. S. K., \& Wardani, I. G. A. A. K. (2018). Skrining Fitokimia Dan Uji Aktivitas Antiinflamasi Ekstrak N-Butanol Buah Dewandaru (Eugenia uniflora L.) Pada Tikus Putih Jantan Galur Wistar (Rattus norvegicus) Dengan Metode Paw Edema Yang Diinduksi Karagenan. Jurnal Ilmiah Medicamento, 4(2), 100-106.

Susanti, N. M. P., Budiman, I. N. A., \& Warditiani, N. K. (2014). Skrining Fitokimia Ekstrak Etanol 90\% Daun Katuk (Sauropus androgynus (L.) Merr.). Jurnal Farmasi Udayana. 
Sutomo, S., \& Iryadi, R. (2019). Konservasi Tumbuhan Obat Tradisional "Usada Bali". Buletin Udayana Mengabdi, 18(4).

Tona, L., Kambu, K., Ngimbi, N., Cimanga, K., \& Vlietinck, A. J. (1998). Antiamoebic and phytochemical screening of some Congolese medicinal plants. Journal of ethnopharmacology, 61(1), 57-65. https://doi.org/10.1016/S0378-8741(98)00015-4

Victoria, F. N., Lenardão, E. J., Savegnago, L., Perin, G., Jacob, R. G., Alves, D., ... \& da Silva Nascente, P. (2012). Essential oil of the leaves of Eugenia uniflora L.: antioxidant and antimicrobial properties. Food and chemical toxicology, 50(8), 2668-2674. https://doi.org/10.1016/j.fct.2012.05.002

Yuan, H., Ma, Q., Ye, L., \& Piao, G. (2016). The traditional medicine and modern medicine from natural products. Molecules, 21(5), 559. https://doi.org/10.3390/molecules21050559

Santoso, P., Dewi, N. L. K. A. A., \& Adrianta, A. (2020). Antioxidant capacity profile of dewandaru leaf (extract eugenia uniflora l.): part of usadha Bali. International Journal of Life Sciences, 4(1), 87-98. https://doi.org/10.29332/ijls.v4n1.407 


\section{Biography of Authors}

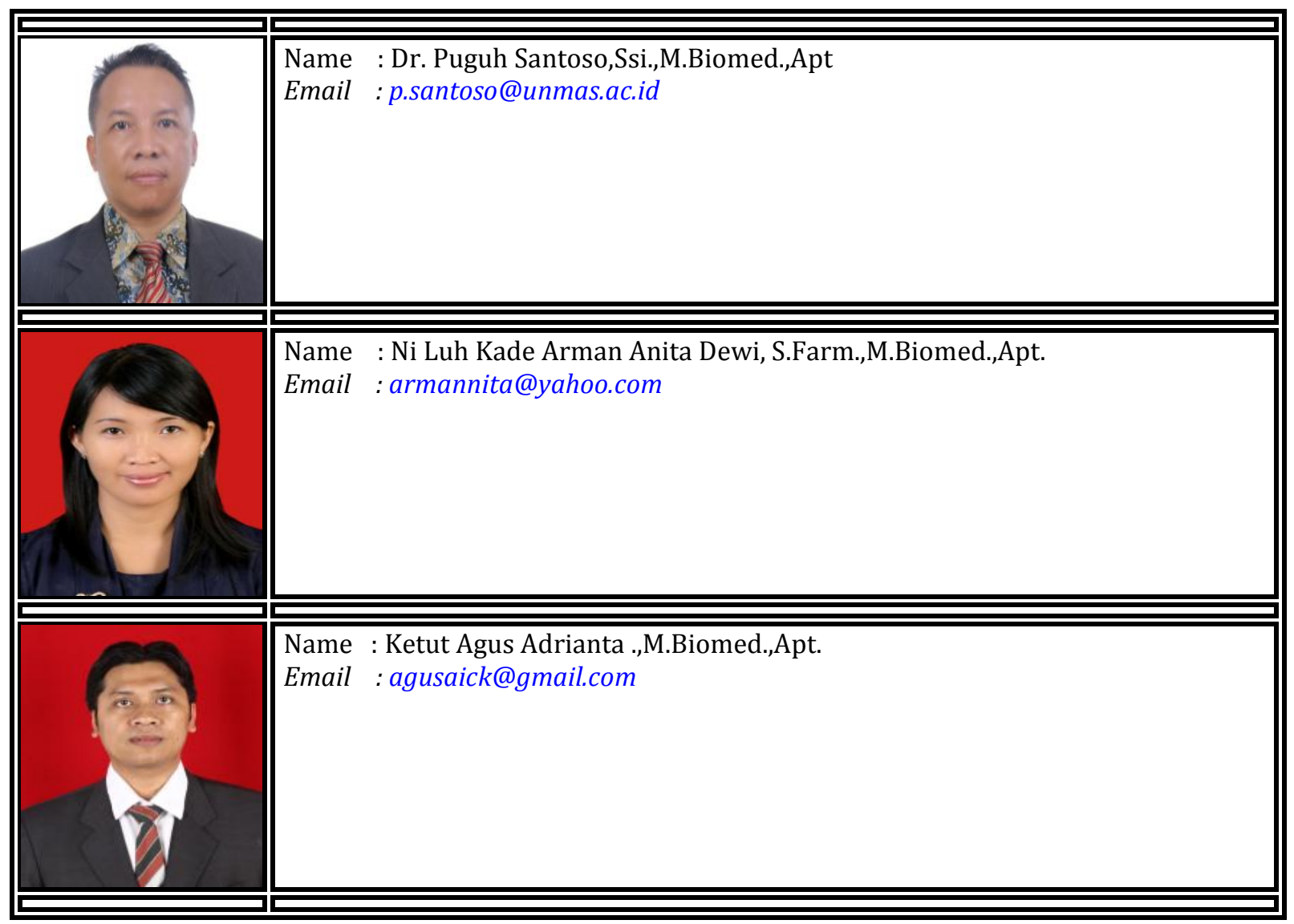

